\title{
AMINO ACIDS FROM Onobrychis kachetica
}

Continuing an investigation of the chemical composition of species of Onobrychis (sanfoin) growing in Soviet Georgia, we have found amino acids in them. It was established by paper-chromatographic analysis that all 18 species of sanfoin investigated had the same amino acid composition, but they differed in the quantitative ratio of the individual components. The leaves and flowers of the sanfoins are particularly rich in amino acids.

To isolate the individual amino acids, $500 \mathrm{~g}$ of the flowers of $\mathrm{O}$. kachetica was extracted with 5 liters of $80 \%$ methanol. The extract was passed through a column of KU-2 cation-exchange resin $(\mathrm{h}=50 ; \mathrm{d}=5 \mathrm{~cm})$, and the column was washed with water and with ethanol, after which the amino acids were extracted with 3 liters of $1 \%$ ethanolic ammonia. The eluate was concentrated to $100 \mathrm{ml}$. The total combined amino acids present in the plant obtained in this way were separated into two fractions by reprecipitation from 10 volumes of acetone.

The separation of the amino acids from the two fractions into their individual components was performed by chromatography on a column of Sephadex LH-20. This gave eight amino acids, which we have provisionally called amino acids 1-8.

The amino acids were identified by one- and two-dimensional paper chromatography in various solvent systems [1] (in parallel with authentic samples), and also by melting points, specific rotations, and elementary compositions.

By comparing the results obtained with information given in the literature $[1,2]$ we came to the conclusion that the amino acids isolated from $\mathrm{O}$. kachetica were the following: 1) L-asparagine, 2) L-serine, 3) L-threonine, 4) L- $\alpha$-alanine, 5) D-proline, 6) L-valine, 7) L-phenylalanine, 8) L-leucine.

TABLF 1. Physicochemical Properties of the Amino Acids of Onobrychis kachetica

\begin{tabular}{|c|c|c|c|c|}
\hline $\begin{array}{l}\text { Amino } \\
\text { acid }\end{array}$ & Formula & $\mathrm{mp},{ }^{\circ} \mathrm{C}$ & {$[\alpha]_{D}^{20} \cdot \operatorname{deg}(c 1)$} & Color with ninhydrin \\
\hline $\begin{array}{l}1 \\
2 \\
3 \\
4 \\
5 \\
6\end{array}$ & $\begin{array}{l}\mathrm{C}_{4} \mathrm{H}_{8} \mathrm{O}_{3} \\
\mathrm{C}_{3} \mathrm{H}_{7} \mathrm{O}_{3} \\
\mathrm{C}_{4} \mathrm{H}_{9} \mathrm{O}_{3} \\
\mathrm{C}_{3} \mathrm{H}_{7} \mathrm{O}_{2} \\
\mathrm{C}_{5} \mathrm{H}_{9} \mathrm{O}_{2} \\
\mathrm{C}_{5} \mathrm{H}_{11} \mathrm{O}_{2}\end{array}$ & $\begin{array}{c}234-237 \\
231 \\
226-228 \\
288-290 \\
218-219 \\
305-308 \\
\text { (decomp.) }\end{array}$ & $\begin{array}{l}-5,34 \text { (water) } \\
+5,95 \text { (water) } \\
+11,5 \text { (water) } \\
-22,5 \text { (water) } \\
+79,0 \text { (water) } \\
+28,9 \text { (2,0\% } \mathrm{HCl})\end{array}$ & $\begin{array}{l}\text { Orange-brown } \\
\text { Violet } \\
\text { Dark violet } \\
\text { Violet } \\
\text { Bright yellow } \\
\text { Bright violet }\end{array}$ \\
\hline 7 & $\mathrm{C}_{9} \mathrm{H}_{11} \mathrm{O}_{2}$ & $270-273$ & $-47,5(2,0 \% \mathrm{HCl})$ & Dark violet \\
\hline 8 & $\mathrm{C}_{6} \mathrm{H}_{13} \mathrm{O}_{2}$ & $\begin{array}{l}\text { (decomp.) } \\
265-270\end{array}$ & $-20,5(2,0 \% \mathrm{HCl})$ & Violet \\
\hline
\end{tabular}

\section{LITERATURE CITED}

1. I. M. Hais and K. Macek, Paper Chromatography, Academic Press, New York, 3rd ed. (1963).

2. J. P. Greenstein and M. Winitz, Chemistry of the Amino Acids, J. Wiley, New York (1961), p. 7.

I. G. Kutateladze Institute of Pharmacochemistry, Academy of Sciences of the Georgian SSR. Translated from Khimiya Prirodnykh Soedinenii, No. 3, p. 446, May-June, 1973. Original article submitted November 28, 1972.

(C) 1975 Plenum Publishing Corporation, 227 West 17th Street, New York, N.Y. 10011. No part of this publication may be reproduced, stored in a retrieval system, or transmitted, in any form or by any means, electronic, mechanical, photocopying, microfilming, recording or otherwise, without written permission of the publisher. A copy of this article is available from the publisher for $\$ 15.00$. 